\title{
НОВАТОРСКИЙ ОПЫТ КРУПНОПАНЕЛЬНОГО ДОМОСТРОЕНИЯ В МАГНИТОГОРСКЕ
}

\author{
ВАРЛАМОВ А.А. ${ }^{1,2}$, РИМШИН В.И. ${ }^{3}$, ТВЕРСКОЙ С.Ю. ${ }^{2}$, ЧИКОТА С.И. ${ }^{1}$ \\ ${ }^{1}$ Магнитогорский Государственный технический университет, г. Магнитогорск, Россия, \\ ${ }^{2} \mathrm{AO}$ «Магнитогорскгражданпроект», г. Магнитогорск, Россия, \\ ${ }^{3}$ Научно-исследовательский институт строительной физики РААСН, Москва, Россия
}

\begin{abstract}
Аннотация. В связи с 90-летием города Магнитогорска рассматривается передовой опыт его строителей в освоении крупнопанельного домостроения. Работа магнитостроевцев всегда отличалась новаторством и передовым опьтом. В 30-е годы ХХ века на стройках Магнитки впервые был применен электропрогрев бетона при зимнем бетонировании, созданы механизмы для разработки мерзлого грунта, организовано производство крупных блоков из бетона на основе доменных шлаков, построены одни из первых в СССР крупноблочные многоэтажные жилье дома В работе приведено описание конструктивных сборных элементов и особенностей узлов их сопряжения в первом крупнопанельном жилом доме СССР, построенном в Магнитогорске в 1951 году. В основу планировочного решения первого панельного здания был положен проект рядовой блок-секции каркасно-панельного дома серии М-1. Отмечены преимущества крупнопанельных бескаркасных жилых домов. Применение полносборной строительной системы по сравнению с традиционной позволило снизить затрать труда в два с половиной раза, сократить сроки строительства в 1,5 - 2 раза, снизить сметную стоимость - на 12 - 15\%. Приведень примеры использования магнитогорского опыты строительства бескаркасных крупнопанельных домов в других городах. Рассмотрены вопросы развития крупнопанельного домостроения в городе, начиная с серий крупнопанельных жилых домов, освоенных в Магнитогорске начиная с 1958 года после пуска в эксплуатацию завода крупнопанельного домостроения. Приведены обобщенные характеристики жильх домов, предназначенных для массовой застройки в разные временные периоды.
\end{abstract}

Ключевые слова: крупнопанельные бескаркасные жилые дома, полносборное строительство домов, стеновые панели, панели перекрытий, строительный комплекс Магнитогорска.

\section{INNOVATIVE EXPERIENCE OF LARGE-PANEL HOUSING IN MAGNITOGORSK}

\author{
VARLAMOV A.A. ${ }^{1,2}$, RIMSHIN V. I. ${ }^{3}$, TVERSKOY S.Y. ${ }^{2}$, CHIKOTA S. I. $^{1}$ \\ ${ }^{1}$ Nosov Magnitogorsk state technical University, Magnitogorsk, Russian Federation \\ ${ }^{2}$ JSC "Magnitogorskgrazhdanproekt", Magnitogorsk, Russian Federation \\ ${ }^{3}$ Research Institute of Construction Physics of RAACS, Moscow, Russia
}

\begin{abstract}
In connection with the 90th anniversary of the city of Magnitogorsk reviewed best practices of builders in the development of large-panel housing construction. The work of Magnitostroi always been innovation and best practices. In the 30 years of the twentieth century in the construction of Magnitogorsk was first applied electric warming up of concrete under winter concreting, established mechanisms for the development of frozen soil, organized the production of large blocks of concrete based on blast furnace slag, built one of the first in the USSR large-block high-rise residential buildings. The paper contains a description of structural precast elements and characteristics of the nodes, their pairing in the first large-panel residential building of the USSR, built in Magnitogorsk in 1951. The basis of planning decisions of the first panel of the building was based on the project ordinary block section of frame-panel houses a series of M-1. The marked ad-vantages of frameless large-panel residential buildings. The use of prefabricated building systems compared with traditional reduced labor costs two and a half times, to reduce the construction time by 1.5 - 2 times, reduce estimated cost by 12 - 15\%. Discussed
\end{abstract}


the development of panel construction in the city, starting with a series of large-panel residential buildings, developed in Magnitogorsk since 1958 after the commissioning of the factory panel construction.

The article presents the characteristics of houses designed for mass construction in different time periods

Keywords: frameless large-panel houses, precast construction of houses, wall panels, roof slab, the building complex of Magnitogorsk.

\section{Введение}

В 2019 году исполняется 90 лет Магнитогорску - одному из самых известных и легендарных социалистических городов. Вместе с городом празднование девяностолетия по праву разделяет трест «Магнитострой», строители которого самоотверженным трудом практически на не обжитой территории воздвигли гигантский металлургический комбинат и город, имеющие важнейшее значение для России.

Работа магнитостроевцев всегда отличалась новаторством и передовым опытом. В 30-е годы XX века на стройках Магнитки впервые был применен электропрогрев бетона при зимнем бетонировании, созданы механизмы для разработки мерзлого грунта, организовано производство крупных блоков из бетона на основе доменных шлаков, построены одни из первых в СССР крупноблочные многоэтажные жилые дома [1,2]. В послевоенные годы развернулось широкомасштабной строительство жилых районов на правом берегу реки Урал. Этот период совпал с реализацией в СССР программы индустриализации строительства.

В 1949 году, ровно 70 лет назад трест «Магнитострой» выступил в роли пионера крупнопанельного домостроения. До этого в Советском Союзе дома бескаркасного типа из крупных панелей не возводились. Первый такой дом был построен в Магнитогорске в 1951 году (рис.1).

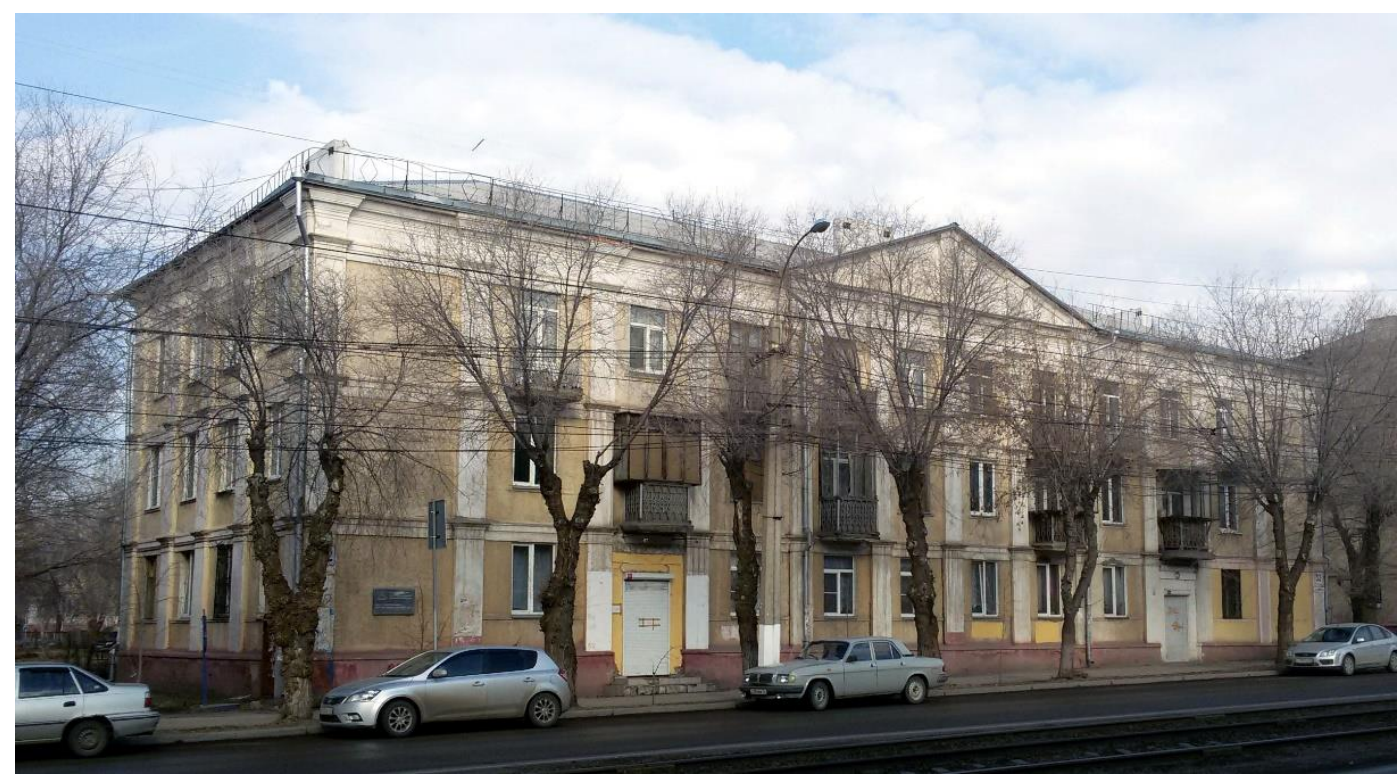

Рисунок 1- Первый крупнопанельный жслой дом г. Магнитогорска 1951 года постройки

Проекты первых трех- и четырехэтажных крупнопанельных домов были разработаны бригадой Академии архитектуры СССР (арх. 3. Нестерова, инж. Б. Смирнов, рук. Г. Кузнецов) [3]. В основу планировочного решения был положен проект рядовой блок-секции серии М-1, спроектированной арх. Л.О. Бумажным для застройки города домами с неполным каркасом [4]. Конструктивная схема была изменена в соответствии с крупнопанельной концепцией: несущий остов сформирован системой внутренних несущих стен, а наружные стены выполнены самонесущими слоистого типа (рис. 2). 


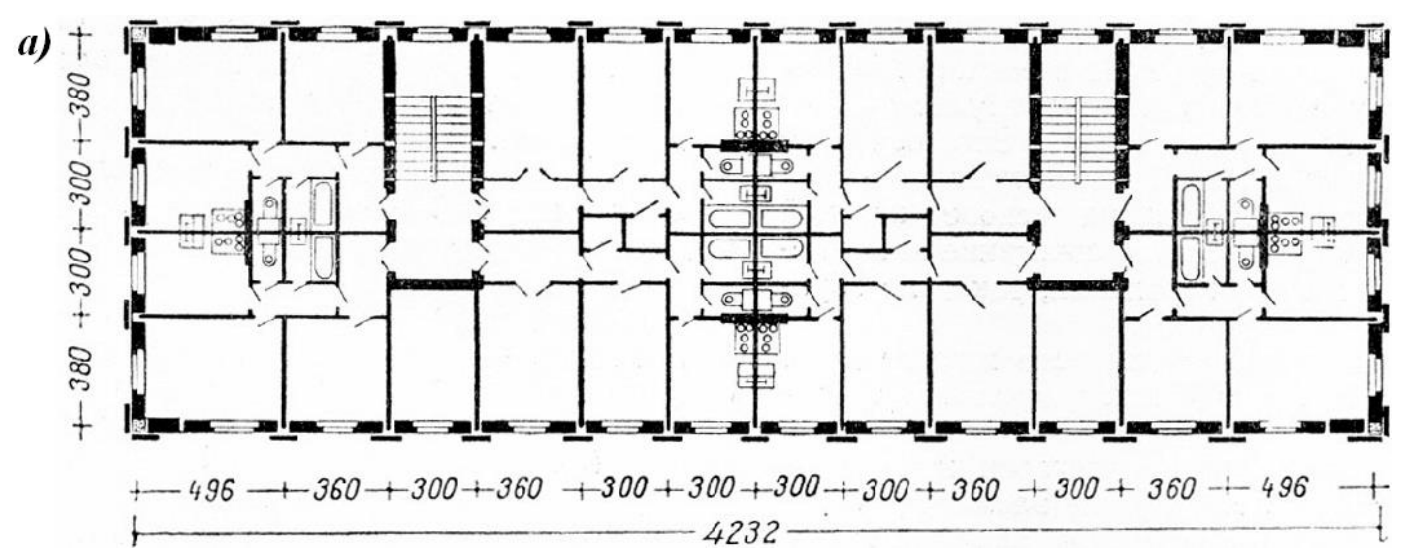

б)

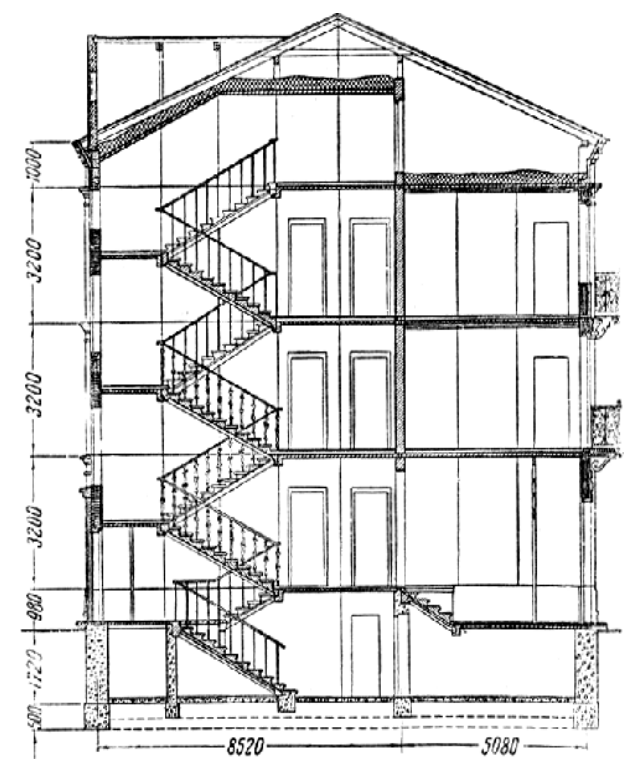

6)

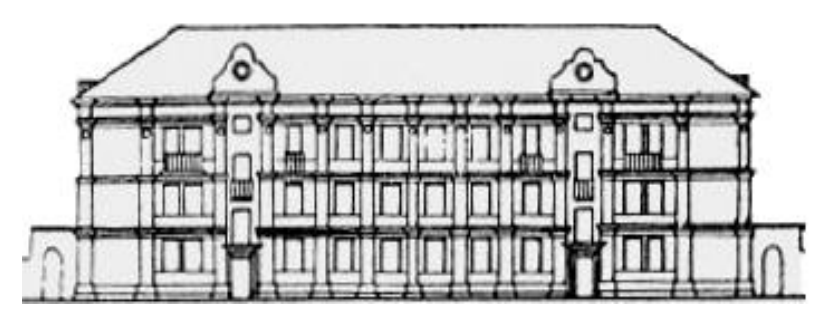

2)

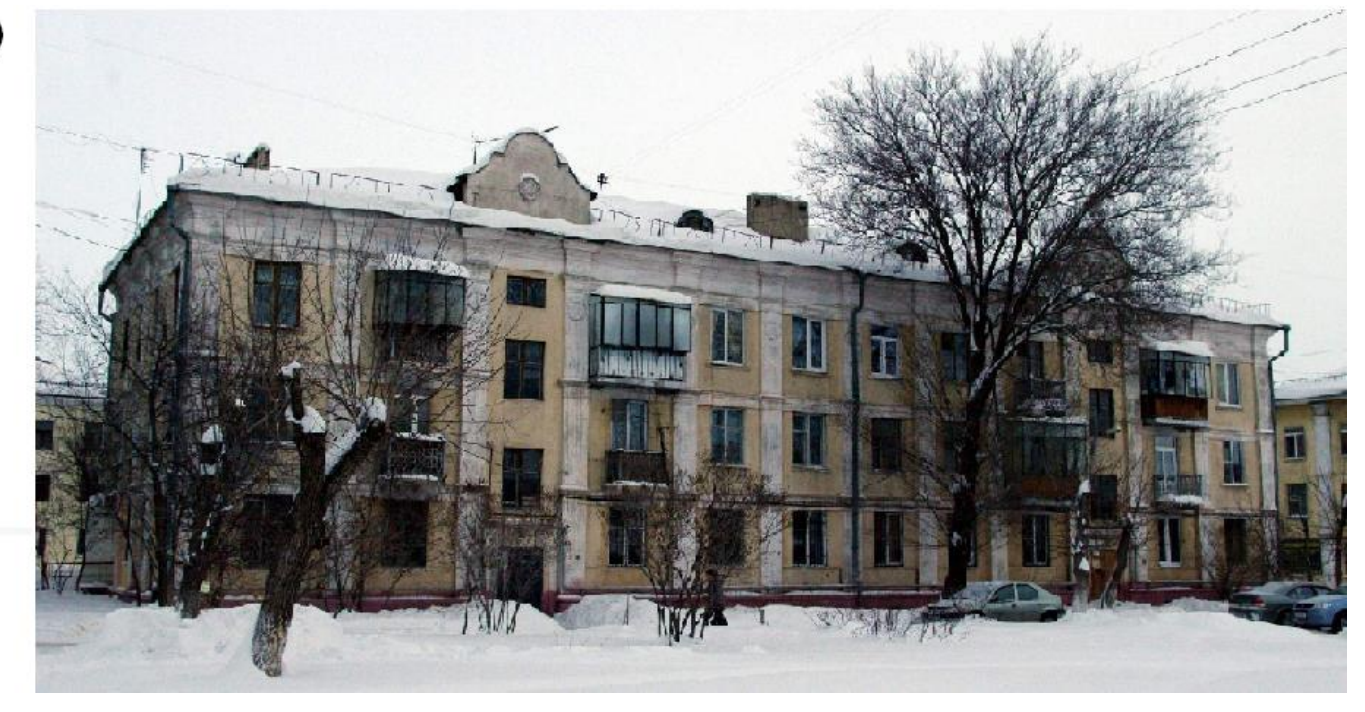

Рисунок 2- Трехэтажный крупнопанельный жилой дом в г. Магнитогорске (1951 2.) [2-5]: а -план; б-разрез; в-фасад; г) - общий вид со стороны двора 


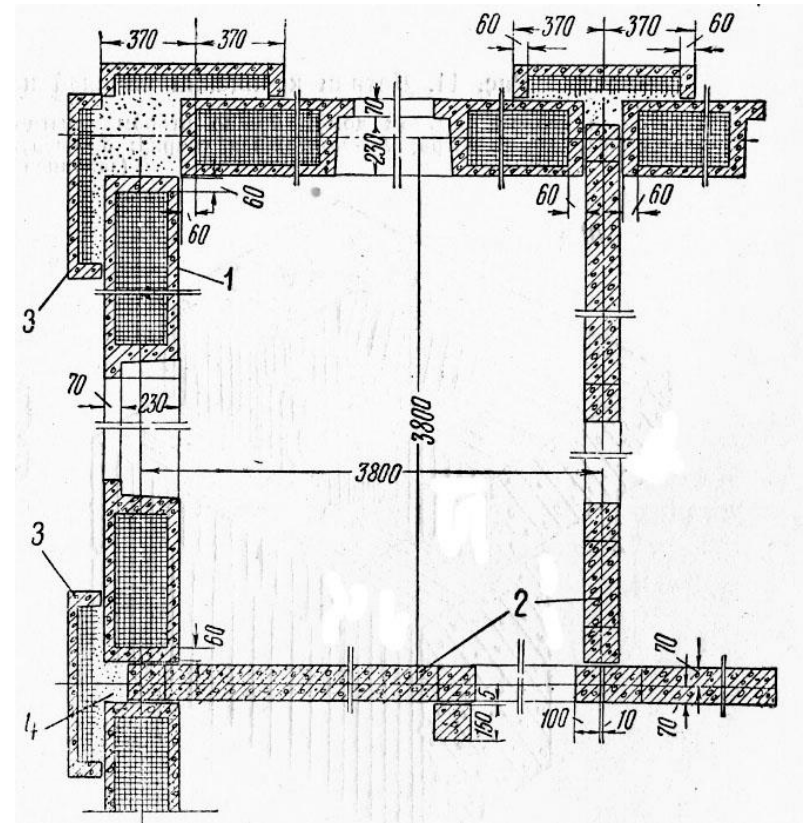

Рисунок 3 - Сопряжение стеновых панелей (план) [4]

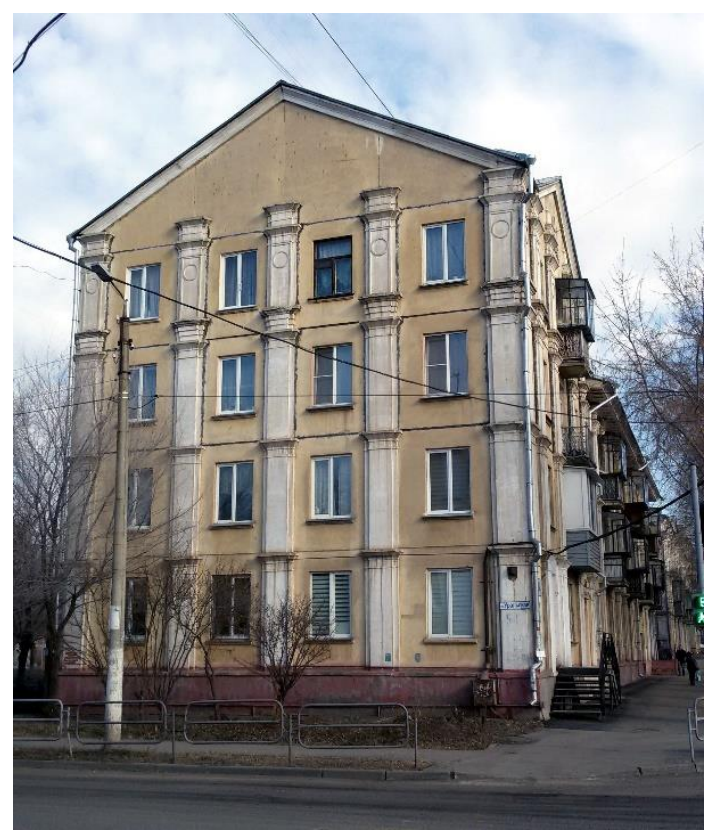

Рисунок 4-Вид фасада с пилястрами

Внутренние несущие панели толщиной 140 мм изготавливали из шлакобетона с обрамлением тяжелым бетоном по контуру панели и контуру дверных проемов [4]. Для возведения дома потребовалось 12 типоразмеров панелей внутренних стен. Наружные стеновые панели имеют размеры на комнату и решены трехслойными с жесткими связями по периметру панели и периметру оконного проема. Средний слой, обеспечивающий теплозащиту - пенобетон, внутренний слой - обычный бетон, наружный фасадный слой - декоративный бетон. Панели наружных стен имеют 4 типоразмера.

В соответствии с принятой конструктивной схемой панели перекрытий опирались тремя сторонами только на внутренние несущие стены. Первоначально изготавливались сплошными однослойными из тяжелого бетона толщиной 90 мм. Впоследствии стал использоваться легкий бетон и панели изготавливаться двухслойными: общая толщина панели увеличилась до120 мм, а рабочая арматура в виде сварных сеток располагалась в слое тяжелого бетона толщиной 30 мм.

При формировании сопряжения стеновых панелей панели внутренних стен заводили между торцами наружных панелей (рис. 3). мм (рис. 4).

Вертикальные стыки со стороны фасада закрывали сборными пилястрами шириой 740

Место стыка заполняли раствором на основе гранулированного доменного шлака. По проекту горизонтальны стыки наружных стеновых панелей имели теплопроводные включения в виде контурных обойм из тяжелого бетона. В процессе строительства было принято решение бетонную обойму на участке горизонтального стыка подрезать, исключив теплопроводные включения, а в монтажный шов добавить конструктивно- теплоизоляционный бетон (рис. 5).

Панели перекрытий опирали на панели внутренних несущих стен нижнего этажа, а стеновые панели последующего этажа устанавливали сверху на плиты перекрытий.

Изготовление сборных элементов первых панельных домов осуществляли непосредственно на строительной площадке (рис. 6). При изготовлении применяли не металлические формы, а простые металлические борт-формы, которые устанавливали на бетонных стендовых площадках [3]. Такая технология позволяла совершенствовать конструктивное исполнение и изменять опалубочные размеры изготавливаемых элементов. 


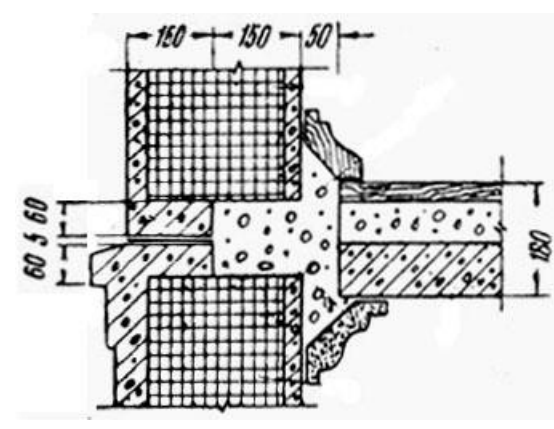

Рисунок 5 - Горизонтальный стык стеновых панелей [4]

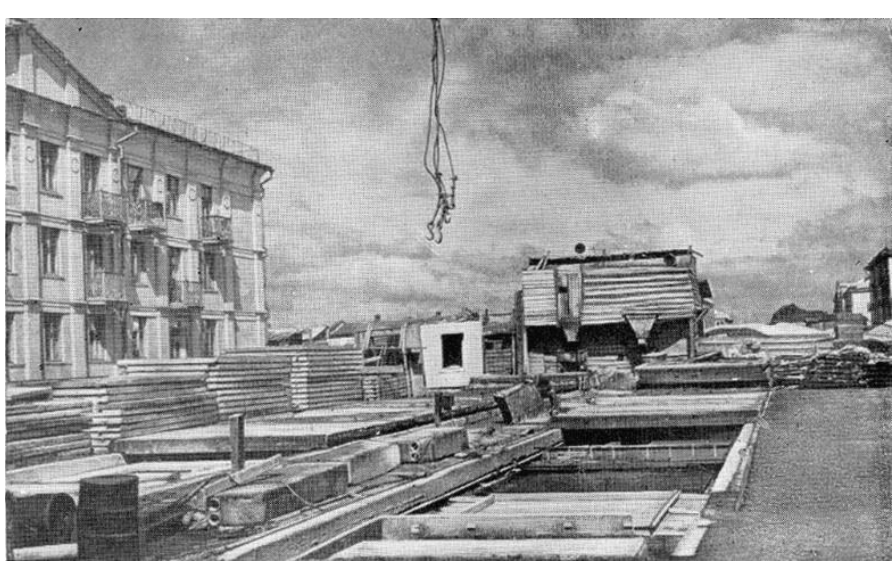

Рисунок 6 - Общий вид полигона по изготовлению крупнопанельных сборных элементов здания [3]

Применение полносборной строительной системы по сравнению с традиционной позволило снизить затраты труда в два с половиной раза, сократить сроки строительства в 1,5 - 2 раза, снизить сметную стоимость - на 12 - 15\%. Отмечались следующие преимущества крупнопанельных бескаркасных жилых домов [5]:

- сокращение числа сборных элементов;

- упрощение монтажа;

- повышенная заводская готовность сборных элементов;

- улучшение звукоизоляции помещений;

- улучшенные планировочные качества помещений;

- снижение металлоемкости.

Магнитогорский опыт строительства бескаркасных крупнопанельных домов был использован в ряде других городов [6]. С 1955 года в Мурманске велось строительство крупнопанельных 4-этажных жилых домов с использованием конструктивных решений, опробованных в Магнитогорске. В 1957 - 1959 годах в Москве при застройке микрорайона Новые Черемушки были возведены три крупнопанельных 5-этажных общежития коридорной планировочной системы, где использованы незначительно переработанные конструктивные решения магнитогорских домов. В Готвальдове, пригородах Праги и Брно (Чехословакия), возведено несколько десятков крупнопанельных домов с поперечными несущими стенами.

Одной из задач опытного строительства являлась подготовка к промышленному серийному производству крупнопанельных домов. Завод крупнопанельного домостроения (ЗКПД) в Магнитогорске начали строить в 1953 году. В 1958 году ЗКПД был введен в эксплуатацию и более чем на пятьдесят лет определил стратегию жилищного строительства в городе.

После пуска ЗКПД был начат выпуск сборных конструкций для крупнопанельных (серия 1-464) жилых домов (рис. 7). В 60-е годы произошел переход на усовершенствованную серию 1-464А. Дома этих серий возводились в городе практически до конца 70-х годов.

В 70-80-е годы совершенствование серий жилых крупнопанельных домов ориентировано на увеличения этажности зданий до 9...16 этажей. С 1976 года ЗКПД освоил выпуск сборных изделий для строительства 9 этажных жилых домов по всесоюзной серии 111-121 (крупнопанельные дома улучшенной планировки) (рис. 8). Появление в этот период поворотных и угловых блок-секций позволило разнообразить застройку и улучшить её выразительность.

С середины 90-х годов и по настоящее время жилые районы в массовом порядке застраиваются крупнопанельными домами новых типов (серия 111-97), главной отличительной особенностью которых является более гибкая планировочная система, вследствие применения большого шага внутренних несущих стен [8-10]. Высота помещений во многих проектах впервые за много лет увеличена до 2,7 м. Все конструкции панелей проходили испытаний в условиях завода и на строительной площадке [11-18]. 


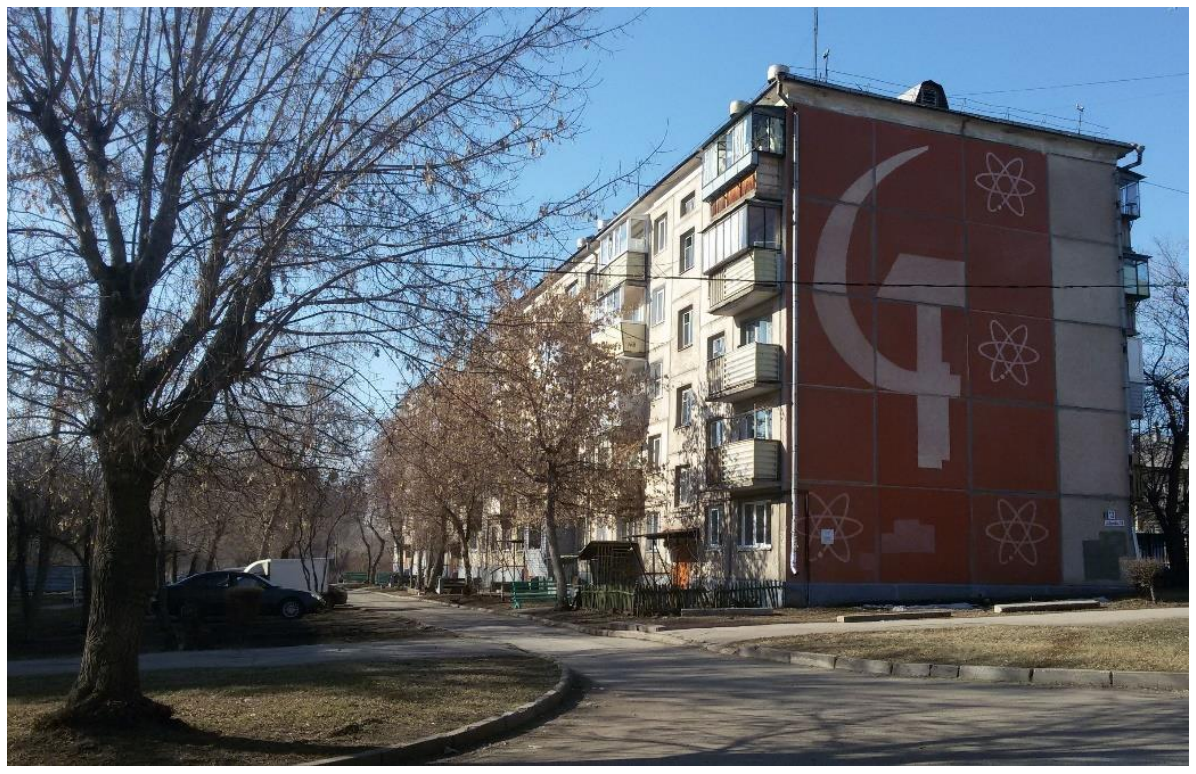

Рисунок 7 - Крупнопанельный жилой дом серии 1-464 60-х годов постройки в г. Магнитогорске
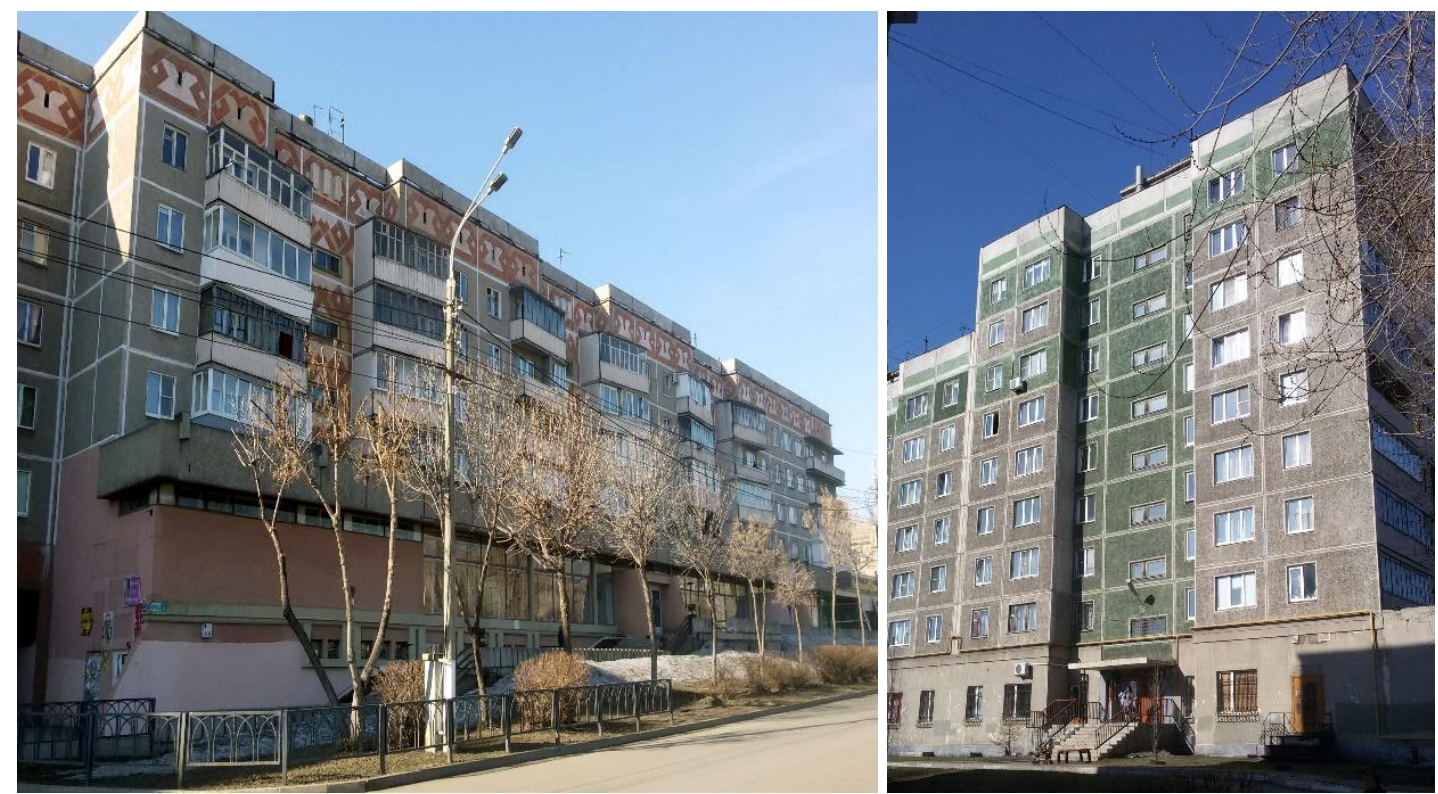

Рисунок 8 - Крупнопанельные жилые дома серии 111-121 80-х годов постройки в г. Магнитогорске

Обобщенная характеристика жилых домов, предназначенных для массовой застройки в разные временные периоды, представлена в таблице 1.

Таблица 1 - Характеристика крупнопанельных домов массовых серий [7]

\begin{tabular}{|c|c|c|c|c|c|}
\hline $\begin{array}{c}\text { Серия до- } \\
\text { мов }\end{array}$ & Годы & $\begin{array}{c}\text { Формула заселения (K - } \\
\text { число комнат, N - коли- } \\
\text { чество проживающих) }\end{array}$ & $\begin{array}{c}\text { Средняя общая } \\
\text { площадь квар- } \\
\text { тир, } \mathrm{M}^{2}\end{array}$ & $\begin{array}{c}\text { Общая средняя } \\
\text { площадь на 1 } \\
\text { жителя, } \mathrm{M}^{2} / \text { чел }\end{array}$ & $\begin{array}{c}\text { Соотношение } \\
\text { жилой и подсобной } \\
\text { площадей, \% }\end{array}$ \\
\hline $1-464$ & $1958-1964$ & $\mathrm{~K}=\mathrm{N}-1, \mathrm{~K}=\mathrm{N}-2$ & 40 & 10 & $83 / 17$ \\
\hline $1-464 \mathrm{~A}$ & $1964-1976$ & $\mathrm{~K}=\mathrm{N}-1$ & 45 & 12 & $66 / 34$ \\
\hline $111-121$ & $1976-2000$ & $\mathrm{~K}=\mathrm{N}-1$ & 55 & 15 & $60 / 40$ \\
\hline $111-97$ & 2000 & $\mathrm{~K}=\mathrm{N}, \mathrm{K}=\mathrm{N}+1, \mathrm{~K}=\mathrm{N}+2$ & $\geq 65$ & $\geq 20$ & $60 / 40$ \\
\hline
\end{tabular}


Строительный комплекс г. Магнитогорска в советский период занимал лидирующие позиции в освоении передовых технологий крупнопанельного домостроения и достаточно полно отражал динамику развития этого процесса в целом по России.

\section{Выводы}

Строительство первого панельного здания в Магнитогорске вызвало огромный интерес к строительству панельных зданий в стране и во всем мире. В настоящее время более $80 \%$ жилых многоэтажных зданий в городе Магнитогорске построено из панелей

Панельное домостроение позволило достичь заметного удешевления строительства при постепенном улучшении комфорта проживания. На настоящий момент себестоимость квадратного метра жилья в городе одна из самых наименьших в стране.

Первому построенному панельному зданию уже около 70 лет. Осмотр здания показал отсутствие коррозионных поражений стыков. Состояние первого панельного здания позволяет прогнозировать срок его службы еще не менее 70 лет.

\section{СПИСОК ЛИТЕРАТУРЫ}

1. Молошников И., Шкарапут А. Магнитострой - пионер строительной индустрии страны // Архитектура CССР. 1979. № 7. С.21-22.

2. Строительство первых крупнопанельных домов в Магнитогорске. Режим доступа: https://vuzlit.ru/1124654/stroitelstvo_pervyh_krupnopanelnyh_domov_magnitogorske

3. Казаринова В.И., Павличенков В.И. Магнитогорск. М: Государственное издательство литературы по строительству, архитектуре и строительным материалам, 1961. -248 с.

4. Смирнов В.Н. Опыт проектирования крупнопанельных домов в Магнитогорске // Архитектура и конструкции многоэтажных крупнопанельных жилых домов. М.: Государственное издательство литературы по строительству и архитектуре. 1954. С. 77-85.

5. Нестерова 3.Н. Особенности архитектурного решения крупнопанельных жилых домов // Архитектура и конструкции многоэтажных крупнопанельных жилых домов. М.: Государственное издательство литературы по строительству и архитектуре. 1954. С. 33-43.

6. Дроздов П.Ф., Себекин И.М. Проектирование крупнопанельных зданий (каркасных и бескаркасных). М.: Издательство литературы по строительству, 1967. 416 с.

7. Магай А.А., Штейман Б.И. Крупнопанельное домостроение России // Жилищное строительство. 2005. - № 12. С. $21-25$.

8. Николаев С.В., Шрейбер А.К., Этенко В.П. Панельно-каркасное домостроение - новый этап развития КПД // Жилищное строительство. 2015.№2. С.3-7.

9. Николаев С.В. Возрождение крупнопанельного домостроения в России // Жилищное строительство. 2012. №4. С. 2-8.

10. Николаев С.В. Возрождение домостроительных комбинатов на отечественном оборудовании // Жилищное строительство. 2015.№5. С.4-8.

11. Варламов А.А., Пивоварова О.В., Пивоваров В.С. Испытание фрагмента сборно-монолитного перекрытия с новым шпоночным стыком // Жилищное строительство. 2012. №5. С.16-18

12. Варламов А.А., Римшин В.И. Модели поведения бетона. Общая теория деградации. М.: ИНФРА-М, 2019. 436 c. www.dx.doi.org/10.12737/ monography5c8a716e3c4460.52838016. - Режим доступа:

http://znanium.com/catalog/product/993546

13. Никитина О.В., Варламов А.А. Анализ экспериментальных данных исследования работы сборномонолитного перекрытия с новым вариантом шпоночного стыка // Вестник ЮУрГУ. Серия «Строительство и архитектуpa». 2015.T.15. №3. C.20-25.

14. Kuzina, E., Rimshin, V., Kurbatov, V. The Reliability of Building Structures Against Power and Environmental Degradation Effects. IOP Conference Series: Materials Science and Engineering463(4), 042009. 2018

15. Бондаренко В.М., Курзанов А.М., Римшин В.И. Механизм сейсмических разрушений зданий // Вестник Российской академии наук. 2000. 70(11), С. 1005-1009.

16. Varlamov A.A., Rimshin V.I., Tverskoi S.Y. The General theory of degradatio // IOP Conference Series: Materials Science and Engineering, Volume 463(2018), Part 1 P.1-6. Doi:10.1088/1757-899X/463/2/022028.

17. Varlamov A.A., Rimshin V.I., Tverskoi S.Y. Durability of buildings in urban environment Materials Science Forum.2018 ISSN:1662-9752. Vol.931.pp. 340-345.

Doi:10.4028/www.scientific.net/MSF.931.340 


\section{REFERENCES}

1. Moloshnikov I., Shkaraput A. Magnitostroj - pioner stroitel'noj industrii strany [Magnitostroy - pioneer the country's construction industry ] Arhitektura SSSR. 1979. No 7. Pp. .21-22. (rus)

2. Stroitel'stvo pervyh krupnopanel'nyh domov v Magnitogorske. Rezhim dostupa: https://vuzlit.ru/1124654/stroitelstvo_pervyh_krupnopanelnyh_domov_magnitogorske.

3. Kazarinova V.I., Pavlichenkov V.I. Magnitogorsk. [Magnitogorsk] Moscow: Gosudarstvennoe izdatel'stvo literatury po stroitel'stvu, arhitekture i stroitel'nym materialam. 1961. 248 p. (rus)

4. Smirnov V.N. Opyt proektirovaniya krupnopanel'nyh domov v Magnitogorske [Experience in the design of large-panel houses in Magnitogorsk] Arhitektura i konstrukcii mnogoetazhnyh krupnopanel'nyh zhilyh domov. M.: Gosudarstvennoe izdatel'stvo li-teratury po stroitel'stvu i arhitekture. 1954. Pp. 77-85. (rus)

5. Nesterova Z.N. Osobennosti arhitekturnogo resheniya krupnopanel'nyh zhilyh domov [Features of architectural decisions Krupnova-nalnyj residential buildings] Arhitektura i konstrukcii mnogoetazhny krupnopanel'nyh zhilyh domov. Moscow: Gosudarstvennoe izdatel'stvo literatury po stroitel'stvu i arhitekture. 1954. Pp. 33-43. (rus)

6. Drozdov P.F., Sebekin I.M. Proektirovanie krupnopanel'nyh zdanij (karkasnyh i beskar-kasnyh) [Design of largepanel buildings (framed and frameless)] Moscow: Izdatel'stvo literatury po stroitel'stvu, 1967. 416p. (rus)

7. Magaj A.A., SHtejman B.I. Krupnopanel'noe domostroenie Rossii [large-panel housing construction in Russia] Zhilishchnoe stroitel'stvo. 2005. No 12. Pp. 21 - 25. (rus)

8. Nikolaev S.V., SHrejber A.K., Etenko V.P. Panel'no-karkasnoe domostroenie-novyj etap razvitiya KPD [Panelframe houses - a new stage of development efficiency KPD] Zhilishchnoe Stroitel'stvo [Housing Construction]. 2015.No2. Pp.3-7. (rus)

9. Nikolaev S.V. Vozrozhdenie krupnopanel'nogo domostroeniya v Rossii [The Revival of large-panel housebuildingtion in Housing] Zhilishchnoe Stroitel'stvo [Housing Construction]. 2012. No 4. Pp. 2-8. (rus)

10. Nikolaev S.V. Vozrozhdenie domostroitel'nyh kombinatov na otechestvennom oborudovanii [The Revival of house-building factories in the domestic equipment] Zhilishchnoe stroitel'stvo [Housing Construction] 2015. No5. Pp.4-8. (rus)

11. Varlamov A.A., Pivovarova O.V., Pivovarov V.S. Ispytanie fragmenta sborno-monolitnogo perekrytiya s novym shponochnym stykom [Test fragment of precast-monolithic overlap with the new keyed joint ] Zhilishchnoe stroitel'stvo. 2012. No5. Pp. 16-18. (rus)

12. Varlamov A.A., Rimshin V.I. Modeli povedeniya betona. Obshchaya teoriya degradacii [Behaviors of concrete. The General theory of degradation] Moscow: INFRA-M, 2019. 436 s. www.dx.doi.org/10.12737/ monography5c8a716e3c4460.52838016. (rus)

13. Nikitina O.V., Varlamov A.A. Analiz eksperimental'nyh dannyh issledovaniya raboty sborno-monolitnogo perekrytiya s novym variantom shponochnogo styka [Analysis of experimental studies of precast-monolithic overlap with the new version of the keyed joint] Vestnik SUSU. Seriya «Stroitel'stvo $i$ arhitektura». 2015.vol.15. No3. Pp.20-25. (rus)

14. Kuzina E., Rimshin V., Kurbatov V. The Reliability of Building Structures Against Power and Environmental Degradation Effects. IOP Conference Series: Materials Science and Engineering 463(4), 042009. 2018

15. Bondarenko, V.M., Kurzanov, A.M., Rimshin, V.I. The mechanism of seismic destruction of build-ings. Vestnik Rossijkoj Akademii Nauk 70(11), Pp. 1005-1009. 2000

16. Varlamov A.A., Rimshin V.I., Tverskoi S.Y. The General theory of degradatio IOP Conference Series: Materials Science and Engineering, Volume 463(2018), Part 1. Pp.1-6. Doi:10.1088/1757-899X/463/2/022028.

17. Varlamov A.A., Rimshin V.I., Tverskoi S.Y. Durability of buildings in urban environment Materials Science Forum.2018 ISSN:1662-9752. Vol.931. Pp. 340-345. Doi:10.4028/www.scientific.net/MSF.931.3401.

\section{Информация об авторах:}

\section{Варламов Андрей Аркадьевич}

Магнитогорский Государственный технический университет, г. Магнитогорск, Россия, канд. техн. наук., доцент, профессор кафедры проектирования зданий и строительных конструкций; АО ПИ «Магнитогорскгражданпроект», г. Магнитогорск, Россия,

главный строитель.

E-mail: mgrp@mgn.ru

\section{Римшин Владимир Иванович}

Научно-исследовательский институт строительной физики (НИИСФ РААСН): Москва, Россия, доктор технических наук, профессор, руководитель института развития города.

E-mail: v.rimshin@niisf.ru 


\section{Тверской Сергей Юрьевич}

АО Проектный институт гражданского строительства, планировки и застройки городов и поселков «Магнитогорскгражданпроект», г. Магнитогорск, Россия,

генеральный директор.

E-mail: mgrp77@mgn.ru

\section{Чикота Сергей Иванович}

Магнитогорский Государственный технический университет. г. Магнитогорск, Россия, канд. техн. наук., доцент, профессор кафедры проектирования зданий и строительных конструкций E-mail: s.chikota@magtu.ru

\section{Information about authors:}

\section{Varlamov Andrew A.}

Nosov Magnitogorsk state technical University, Magnitogorsk, Russian Federation, candidate in tech., associate prof., prof. of the dep. the design of buildings and building structures E-mail:mgrp@mgn.ru

\section{Rimshin Vladimir I.}

Research Institute of Construction Physics of RAACS, Moscow, Russian Federation, Doctor of Sciences (Engineering), Corresponding Member of RAACS, Head of Institute of City Development E-mail: v.rimshin@niisf.ru

\section{Tverskoy Sergey Y}

JSC "Magnitogorskgrazhdanproekt", Magnitogorsk, Russian Federation, General Head

E-mail: $\underline{\text { mgrp77@mgn.ru }}$

\section{Chicota Sergey I.}

Nosov Magnitogorsk state technical University, Magnitogorsk, Russian Federation, candidate in tech., associate prof., prof. of the dep. the design of buildings and building structures E-mail: s.chikota@magtu.ru 